This item was submitted to Loughborough's Research Repository by the author.

Items in Figshare are protected by copyright, with all rights reserved, unless otherwise indicated.

\title{
Business archives and local communities: corporate heritage in Loughborough, UK
}

\section{PLEASE CITE THE PUBLISHED VERSION}

http://dx.doi.org/10.1080/23257962.2017.1336615

\section{PUBLISHER}

(C) The Authors. Published by Taylor and Francis

\section{VERSION}

AM (Accepted Manuscript)

\section{PUBLISHER STATEMENT}

This work is made available according to the conditions of the Creative Commons Attribution-NonCommercial 4.0 International (CC BY-NC 4.0) licence. Full details of this licence are available at: https://creativecommons.org/licenses/by-nc/4.0/

\section{LICENCE}

CC BY-NC 4.0

\section{REPOSITORY RECORD}

Ravenwood, Jonlyn Clare, and Tim Zijlstra. 2019. "Business Archives and Local Communities: Corporate Heritage in Loughborough, UK". figshare. https://hdl.handle.net/2134/25462. 


\title{
Business archives and local communities: corporate heritage in Loughborough, UK.
}

Key words: archives, communities, business archives, archive management, corporate memory.

\begin{abstract}
The LoCHe project investigated corporate archives, focusing on the case of Loughborough, a market town in Leicestershire, UK. The potential benefits for the business from creating and managing a company archive are great and the local community also benefits, but this reciprocal relationship and its associated challenges has not been widely examined. Through analysis of interviews and focus groups with a variety of stakeholders, it explored the relationship between businesses, archives and the local community. The project found that corporate archives are considered important to local enthusiasts as a source for historic research, and help inform local and work identity. Individuals are key to collecting and preserving material both in the community and the business, but community members are often unable to contribute to or access business archives. Also there is a disconnection between stakeholders which results in an ad hoc and confused local picture. The impact of digital is yet to be felt except in limited ways. It also revealed that corporate archives are often treated as an afterthought by businesses, which potentially leads to the loss of archives due to lack of interest, resources or skill to manage it appropriately.
\end{abstract}

\section{Introduction}

An intrinsic and previously unexplored relationship between the history of a community and local businesses can be analyzed by investigating the roles and relationships of corporate 
archives and potential users of such archives. The literature describes why a business should have an archive and the potential benefits for the business from it ${ }^{1}$. Archives can be used to increase brand awareness through marketing and customer relations activities, to differentiate the company from competitors, and provide a memory of the business and evidence to protect the company against litigation or reputational damage. The local community also benefits in numerous ways from businesses collecting and making use of their heritage, but this reciprocal association with benefits and problems for all stakeholders has not been widely examined. Businesses are not separate from their communities but instead can help to promote community identity though interaction with their archives and some of the challenges and opportunities that can be created at the intersection of business, archives and community are examined in this paper, along with questions of custody, collection and dissemination. The focus here is on businesses that operate their own archives, rather than the approach of keeping business records in local authority archives or managed by The National Archives (TNA). In particular the research is concerned with the issue of heritage in small and medium enterprises ('SMEs') i.e. those with under two hundred and fifty employees (as defined by the European Commission on their website ${ }^{2}$ )

The paper is based on research undertaken by the authors as part of an AHRC-funded project ‘LoCHe’ (Loughborough Corporate Heritage), which took place in 2016. This project focused on the use of business archives for anniversary celebrations, including investigating whether digital material was involved. Company milestones, such as a centenary anniversary, can trigger a business to pay attention to its heritage and available archived material. These collections may also include artefacts and digital material. However during the project an important theme that emerged was the relationship between companies, their archives and the 
local community. Corporate archives are of benefit to the local community, but the relationship between the two has not been widely explored before in the context of a market town such as Loughborough. The project established relationships with local interest groups, enabling engagement and knowledge exchange with the local community through interviews, focus groups and an open day for the public held at Loughborough Public Library. It built relationships with a number of local businesses, along with the local authority archives, gaining and advocating a better understanding of the extent, use and value of corporate archives, in particular related to corporate anniversary celebrations. Visits to 'best-practice' corporate archives were undertaken as well as visits to The National Archives and the Leicestershire Records Office, to better understand the corporate archive landscape.

Loughborough is a market town in the borough of Charnwood in north-west Leicestershire. Charnwood had a population of 176,700 in 2015 , with approximately a third of these living in Loughborough (2015 figures can be found on the Nomis official labour market statistics website $^{3}$ ). The area has recently been named the most 'average' place in Britain measured by age, average wages, house prices and the results of the recent EU referendum, according to the Leicester Mercury newspaper. ${ }^{4}$ Its ordinariness makes it an interesting case for research into relatively small, regional corporate archives and the local community. The town does not have strong links to traditional heavy industries that other similar market towns in the East Midlands have, such as mining in Mansfield, but it has interesting historical links to the industrial revolution and engineering has been a significant industry in the town. For example the Luddites destroyed new lace making machinery in the town in 1816 which meant the inventor and owner of the factory, John Heathcoat, moved to Devon. This prompted a walk from Loughborough to Tiverton by five hundred workers, thus establishing the Tiverton lace- 
making industry. ${ }^{5}$ Loughborough has a proud industrial heritage; well-known companies founded in Loughborough include Ladybird books, Brush Electrical Engineering and John Taylors Bell Foundry. According to the most recent Office for National Statistics data ${ }^{6}$, Charnwood has 7430 enterprises, of which 3705 are SMEs. Larger companies include 3M Health Care, Fisher Scientific UK, and Hancocks Topco which are based in Loughborough. The town is also home to a very highly regarded University, which has helped to create and attract a range of high technology companies.

Loughborough's rich industrial heritage is evident throughout the town, providing a rationale for focusing the research in this area. Local community groups have a strong interest in protecting this heritage and organise regular activities to celebrate local heritage. Recent examples include an exhibition in the local library focused on Loughborough Building Society, a financial services company founded in the town that is celebrating its $150^{\text {th }}$ anniversary and an exhibition celebrating the work of artists commissioned to create works for Ladybird books when the company was based in the town.

\section{Business archives}

In order to focus attention on business archives in 2009 The National Archives launched a National Strategy for Business Archives for England and Wales ${ }^{7}$; in Scotland the National Strategy for Business Archives in Scotland was developed in 2010 on behalf of the Scottish Council on Archives ${ }^{8}$. The TNA National Strategy was developed to raise the profile of corporate archives and to promote the benefits of well managed archives to businesses across the country. It defines business records as; 
'...the physical evidence of business activity - created, received and maintained as evidence and information - and exist in a variety of media formats including paper, digital and audio-visual’ Business archives are records that companies or collecting repositories choose to keep permanently, for commercial, legal and historical reasons. $^{, 9}$

The Strategy describes corporate archives as lacking a unified approach and states that in England and Wales there are very limited statutory requirements to maintain business archives ${ }^{10}$.Many corporate archives are ad hoc parts of the business, despite the efforts of organizations such as the Business Archives Council and ARA (including the Section for Business Records) to advocate for company archives and archivists.

Business archives are important yet underutilized not only by historians but also by those interested in particular business practices ${ }^{11}$. The focus in the literature on business archives tends toward the practicalities of how to use them effectively; many of the available resources, such as those listed on the ARA Business Records specialist section website (as of $2017^{12}$ ) are for those looking to use or find business archives for research for instance. However there is little regarding issues specific to business archives themselves, although this is in part unsurprising as the principles and techniques that are applicable in other types of archives are of course equally applicable in a business context. Nevertheless, records and archives created and held by companies are subject to different contextual pressures and so require specific consideration. This reflects the lack of attention paid to business archives in the wider community and the corporate world. 
For those companies that do have active archive teams there is an emphasis in the literature and guidance on managing business records; this is unsurprising as businesses are more likely to be concerned with the management of current records that are of use for evidentiary or risk management purposes than in keeping historic material. However as the Digital Preservation Coalition explain in the 'Digital Preservation Handbook' (available through their website), the increased ubiquity of digital material challenges traditional archive and record keeping practices $^{13}$ and there is expertise on digital preservation found in the archives sector that business could benefit from. There is also the inherent value of a company archive to consider, both to the company and the wider community, and the TNA publication on Corporate Memory ${ }^{14}$ along with the 'Managing Business Archives ${ }^{15}$ website describes many of these. They include helping to create a distinct identity and improved brand management, marketing, and the development of new products and packaging; the emphasis is on archives as a business asset. Additionally Deserno discusses the value to society of the archives of large multinationals ${ }^{16}$. She discusses specific examples where multinationals were unable to utilise their archives to stave off public criticism by opening up how certain decisions were arrived at or indeed how certain problems arose over time. She argues that openness of these archives is important to aid corporate governance, accountability and transparency. This message is repeated by Shepherd ${ }^{17}$ about archives in general; archives aid accountability and espouse the value of openness and transparency.

The potential loss of corporate memory resulting from poor, or non-existent, archiving has a cost to the business, particularly with an increased digital material focus. Digitally created material can become lost easily without appropriate standards to preserve and manage it. In addition Megill ${ }^{18}$ argues that increased staff time in searching for documents, increased risk 
to reputation and from litigation, and costs of storage are all issues that businesses face if records and archives are not properly managed and valued. The TNA National Strategy ${ }^{19}$ discusses the vulnerability of business archives and identifies a number of underlying factors. These include the rarity of professional teams to organize records and archives within businesses; the failure of businesses resulting in ad hoc rescues; statutory limitations on how long records should be kept, or a lack thereof; a lack of clarity about the records of new companies in the 21st century, in particular internet-based companies; and finally the rise of electronic records and the risk of loss of born-digital material in particular. It also discusses the fact that activities such as mergers and acquisitions between companies leads to a loss of corporate archives. Whilst arguably these factors may affect large companies to a greater degree, it is not difficult to see how they could also impact on SMEs as much if not more. This means that a large proportion of corporate heritage is at risk; the Federation of Small Businesses on their website note that $99.9 \%$ of all private sector businesses in the UK at the start of 2016 are SMEs ${ }^{21}$. Comparisons between large companies and SMEs are not entirely suitable however, as companies differ greatly in terms of available resources and the professional approach to collection and care of archival material employed, but as there is very little research focused on archives in SMEs this seems inevitable.

Traditionally 'outreach' by corporate archives might have been through events or exhibitions but now it is commonly performed through a company website which may have a 'History of the company' webpage or similar. Since Gray’s reflective piece in 2002, where he highlights this 'new electronic marketplace' 22 there seems to have been little change though in the appreciation by business of the value of their material. There is still a need to extoll the virtues of archives to business, wherein the archive can support and add value to the business, 
and there are still relatively few business archives. There is a paucity of business archives; TNA estimated that a mere $20 \%$ of FTSE 100 companies had in-house archives ${ }^{23}$. However Gray does highlight that some companies realised that the archive can act as 'a bridge' between the company and the outside world ${ }^{24}$. The examples that he gives include academic researchers and local schools, but little consideration has been given to this further, even though companies can have a huge impact on the lives of employees and their families and hence the local community. Of interest to the LoCHe project is the impact of company anniversaries, which may celebrate the company alongside employees and ex-employees, both as a driver to engagement and to collecting. This is highlighted by TNA in a series of case studies, in which companies such as Marks and Spencer ${ }^{25}$ and Thomas Cook ${ }^{26}$ used archival material in their anniversary celebrations, demonstrating that historical company material has ongoing value in tracing the 'story' of the company.

\section{Community archives}

Whilst the benefits to business of investing in business archives have been made clear, the relationship to the wider community is more obscure. Different perspectives on communities and archives have been put forward, in particular of 'community archives' that may incidentally contain business records or information. Flinn ${ }^{27}$ gives a clear overview of the types of community archive and their development. He also points out that defining what a 'community' is, let alone a 'community archive', is difficult; he prefers to give a definition of community as a group that define themselves as such which though broad seems appropriate $^{28}$. The common characteristic recognized is of communities collecting in some organized way. Flinn goes on to identify family history as an incentivizing factor in the growth of community archives ${ }^{29}$, and this seems also to be a driver toward community engagement with company archives. Of interest here is work by Barrett ${ }^{30}$ on personal 
archives found within the archives of companies, in which the division between personal and company records is blurred; this leads to difficulties with traditional archival theory. Barrett suggests that archives are considered through the lens of a personal 'work identity', constructed by employees or company owners, which leads to the blending of personal and corporate records. This concept suggests that the personal aspect to work may act as a driver not only to creating records, which archivists then find in corporate archives, but also to the public interest in collecting and using corporate records that reflect the individual's lived experience.

The concept of a 'participatory archive' has been explored by Gilliland and McKemmish in which they articulate a vision of community-based participation in archives ${ }^{31}$. They focus in particular on archives associated with trauma and human rights, such as from dictatorial or genocidal regimes. They make the point that community archives can be a response by communities who do not feel their needs are met by existing archives and they may place value on different kinds of 'records'. This is more than engaging with institutional or local authority archives, instead collecting and curating material of importance to themselves and their community. Gilliland and Flinn also discuss 'community archiving' in which the creation of these types of archives is a criticism of mainstream institutions ${ }^{32}$. Whilst business archives in the UK clearly should not be positioned in the same human rights context, these concepts are relevant to the relationship between communities and business archives. Some of the characteristics of community-based archives identified and the motivational factors behind them discussed by Gilliland and Flinn have a resonance here ${ }^{33}$. In particular the aim of creating the archive as a living, useful, collection that is used in the present for identity purposes, producing knowledge and building solidarity, which could underpin the 
participatory nature of the potential of the business and community relationship. This is further explored in the rest of this paper.

\section{Methods}

To investigate the wider implications of corporate archives in the Loughborough area a local activist was engaged with the project to gain insight into the various local community heritage groups in Loughborough. This included the local Library Heritage Group, the museum, and various local people in the community with an interest in local history. A special event was held in the public library of Loughborough to engage with the general public with the aim of collecting stories and memories about businesses in the area. This resulted in the identification of businesses that had a historic impact on the town, some of which still operational, such as Brush Electrical Engineering and the Loughborough Building Society and others that have closed over time, such as Ladybird, Astra Zeneca and Fisons. Interestingly several smaller businesses were mentioned frequently as well, in particular Tyler’s a well-established local wine merchant and Pickworths Furnishings, which has a history going back to 1840 .

This resulted in a number of interviews, either by phone, e-mail or in person with representatives of several of these businesses. Simultaneously contacts with the local heritage groups were cultivated and a focus group session took place with local heritage activists. To benchmark findings it was decided to seek out best practice corporate archives. Interviews were held with representatives of Marks and Spencer’s Archive in Leeds and British Telecom Archives in London. To gather professional insight into corporate archives interviews were 
held with a corporate archive representative at The National Archives and the archivist from Leicestershire County Council.

The collected data was analyzed using constant comparative analysis with a thematic approach and a number of themes were identified early on in the project. These included the importance of celebrating anniversaries for the local community, the loss of historical material due to indifference, the role of the community in collecting business history despite the companies concerned and the frustration felt by community, businesses and local heritage professionals alike in collecting, managing and using historical company material. These themes will be explored further in this paper.

\section{Findings and discussion}

\section{Awareness of benefits}

A key finding is the lack of interest of some businesses in their heritage. This can be attributed to a lack of awareness regarding archives and understanding of their potential value; for many businesses archives represent only a cost without benefit and this was expressed by the businesses in this project.. The companies involved in the research who were interested in their heritage revealed a number of motivations, focusing in the main on a short term view where an immediate use, such as for an anniversary celebration, was identified. A holistic view of the benefits for business was missing, indicating that promotional work around business benefits would be beneficial; the TNA strategy is now seven years old and there may be an argument for a restatement of the advantages archives can bring, including to SMEs. 
A related issue is the general lack of understanding about the role and value of professional record-keepers and archivists; for example the marketing manager of a financial services company was the only interested senior manager at the company, which is typical. Apart from Taylor's Bell Foundry, which is based in Loughborough and has a museum on site, none of the companies explored in Loughborough are known to employ archivists or recordkeepers. This is unsurprising; large companies are able to do this more readily than smaller local companies which form majority large proportion of Loughborough’s corporate environment. Awareness of local archives as well as accessing or saving them from destruction is a problem for the archives sector as well as for local companies and enthusiasts. This leads to a need to highlight community benefits in terms of greater awareness, access and use of archives, both for local activists as well as businesses in order to help with motivation, as well as highlighting a need for further research into community collecting, the role of enthusiasts and corporate archives.

\section{The importance of individuals}

The project highlighted the importance and role of local people in collecting, especially when the company itself does not collect its own heritage. Individuals may act as collectors, as repositories of memories, as drivers to collecting, and as drivers to preservation. Local history enthusiasts (activists), or people who used to work for the company, acquire these roles and the material they collect, along with memories of working in a company, is of great use in anniversary celebrations. An example of this was given by an interviewee who is both a local expert on the town and a former employee of a large company. The company celebrated an anniversary in 1979 and there would have been little celebration if the interviewee and like-minded friends had not organized one using archive material and 
artefacts they had collected themselves. The company clearly did not recognize the benefits of engaging with their own heritage at that time in order to gain the public relations benefits described by TNA and illustrated currently by large companies such as Marks and Spencer’s, through their museum in Leeds. This may be related to the sector in which the company operates as some sectors, such as retail, may have clearer or more easily achieved benefits than others, such as engineering or pharmaceuticals. However the companies involved in this research who were interested in anniversary celebrations or were planning them were very clear on the public relations benefits that would accrue through the celebrations, including marketing their brand and accentuating their legacy for the local area.

The role of local enthusiasts and community collecting for anniversary celebrations seems generally undervalued, as the evidence in this project suggests that there is little contact between the company and community stakeholders, including heritage professionals and enthusiasts. Exceptions to this are when a company has little in the way of their own collections but have identified a use for historical material, such as for anniversary celebrations. For example a local financial services company as part of an upcoming anniversary would like to use material from the past, for marketing purposes and to accentuate its legacy for the local area. However its archives were lost in a flood several decades ago as the material was stored in a cellar. The society decided to employ a local amateur historian to find and retrieve as much old material as possible from other sources, but this is proving to be more difficult than anticipated. It is unclear how far companies work with groups in the local area outside this specific type of instance; enthusiast respondents reported not knowing what to do with much of the material they collect as companies are disinterested and heritage organizations do not have the capacity to deal with collections. The 
enthusiasts discussed at length the lack of interest shown by local companies, which to them is a missed opportunity, especially for anniversaries. One problem is that the enthusiasts collect on an ad hoc basis, where material relating to local businesses or former workplaces may be found in many different places without necessarily being organized In contrast the companies themselves may have an interested individual who drives collecting and preservation activities. This may be for personal reasons, as in the case of a small local but long established family firm where the company records and other heritage material had been kept as evidence of family history. In the financial services company case, the marketing manager was the driver behind the interest in archival material, but she stated that other senior management had little interest.

Flinn ${ }^{34}$ discusses the need for collaboration and the building of relationships between archive services and community archives, but this research has shown that this collaboration could also include local businesses and individual community members or groups. This would help to ensure collections are collected, stored and made available in ways that will benefit companies, the community and archivists alike. Because much of the collecting in the community, whether by individuals or local services, is ad-hoc, fragmentation and a lack of communication between stakeholders puts material at risk. The issue is particularly pressing when an individual enthusiast or a company 'champion' retires or moves jobs as this can lead to the loss of material or interest by the company. Problems may arise when the individuals are no longer interested or able to collect or drive the care of the archive; as mentioned by Gilliland and Flinn ${ }^{35}$ it is at this point that community archives, and as mentioned by the local authority archivist in this project also businesses, might approach mainstream archives for assistance. 
In this project it was clear community respondents were collecting to document the life of the town as they knew it, as this was a source of local pride and could be used now as part of their work place identity and for education both for themselves and other local residents and visitors. Collections in local authority archives, companies, and people’s lofts are all part of recording the local story as well as being a reflection of the collector's own work identity and life story. As Gilliand and Flinn mention, this may be perceived as a threat by archivists, who may view an 'archive' very differently ${ }^{36}$. But there is an active and engaged scene of amateur historians (at least in Loughborough) that produce literature on local history, including corporate history, which use local authority archives extensively and this relationship should be encouraged as it would benefit all stakeholders; the local authority archivist was keen to encourage this. . In addition to links with local authority archives, similar connections could be made to other heritage and tourism services, such as the local museum, which was keen to celebrate the history of a particular business founded on the town but were unable to, as the parent company refused permission for the museum to include materials still in copyright. This seems like a missed opportunity for the company, as allowing others to exploit the companies' history would be of marketing and public relations benefit. This research seems to indicate that this type of opportunity is not always considered by companies and the benefits of building relationships with local groups and organizations to not only collect material but also to bring this to audiences, and hence take advantage of the opportunity for marketing, are not necessarily appreciated.

This example and others described in this paper highlight two further issues, firstly that of copyright and usage rights relating to materials of an ongoing business. Clearly the copyright owner can restrict copies being made and communicating or presenting material to the public. 
Whilst there are exemptions related to non-commercial research, there may be limitations on the use that can be made of material collected by all stakeholders. In the case of the museum the company was keen to retain control of its material in order to protect its ability to benefit economically from it; according to the respondent this meant they were unwilling to allow use of it even by a non-commercial organisation. This is a complex area and advice should be sought; there is literature available, such as from TNA specifically for archives. ${ }^{37}$, but this is another example of where collaboration between stakeholders can produce benefits. Secondly there are issues with access. For example it became clear that local heritage enthusiasts experience barriers to finding and using material related to issues such as travel to the Records Office, finding material and awareness of catalogues. This hinders their use of materials, thus potentially undermining the value of their own collections and their motivation for preserving or curating it effectively

\section{Family history}

Several local small family-owned retailers are engaged with collecting their heritage, including a long established wine merchant. The reason that these companies maintain archives seems to be because they are private, family-owned collections and it is for family rather than business reasons that material is kept, reflecting the discussion by Barrett mentioned previously. In the case of large businesses, such as Marks and Spencer's, family archives formed the foundation for the current modern-day archive. The issue with small family-run businesses is that such archives are not documented and largely inaccessible, nor are they stored appropriately, meaning that they may eventually be lost. The example of the wine merchant illustrates this as the records were collected and kept in an ad hoc manner, in drawers and boxes, depending on the interest of various family members. This issue was also 
raised by TNA and Leicestershire Records Office; many corporate archives are undocumented and even if they might be of historic significance many are lost when businesses fold or are bought by competitors. Examples of this were given by an interviewee from a long established company in the town who described watching records being disposed of in a skip when their employers were acquired by a larger company. With smaller, local companies, local records offices may not be aware of these events and due to limited resources it is difficult for them to respond.

\section{The issue of digital}

With the advent of digital-born material it is increasingly obvious that bad habits regarding archiving are being carried forward despite a whole new agenda emerging with digital preservation. This lack of awareness will inevitably lead to issues of irretrievability and preservation of digital material for businesses. Awareness of the potential and the risks associated with digital material seem not well understood; little attention is paid to digitization for preservation for example. Not only are digital corporate archives not created, but those that exist may be at risk as it requires management understanding and 'buy-in' to protect archives (in whatever format) and this is subject to 'the flavour of the day' - when management changes the necessary buy-in and support might change with it and this could threaten preservation activities. The engineering company in Loughborough does not have a formal managed digitization process but has begun to digitize certain types of material, such as plans or engineering drawings, on an ad hoc basis when they need to be used and there is recognition that this is one way to not only make these more available but also to help preserve the original material. It was obvious that although there was a need for appropriate records management, it fell upon the IT department, rather than a professional records 
manager, to provide solutions for the issue. Not having clear lines of responsibility for digital material can undermine efforts to keep it in the longer term ${ }^{38}$ so this is a concern as it is unlikely to be confined only to businesses in Loughborough.

\section{The issue of loss}

From the analysis of the data it became clear that companies found it difficult to justify spending resources on managing an archive effectively. A variety of examples were given which illustrate what can be lost and the effect this had on the town and the local community.

In the case of a local engineering company their records are slowly being digitized, but the ad hoc nature of the process over a long period of time has led to fragmentation of the records. The company holds physical material and material on microfiche that now needs to be digitized and material is stored in a number of different digital databases. The physical material in particular is stored in inappropriate conditions and has almost been lost in a fire incident twice. Although this does not equate to corporate memory loss at the moment, the ad hoc approach increases the risk to the material and demonstrates a lack of appreciation of records management.

There has been corporate memory loss in two distinct cases however. Interviews with local amateur historians also revealed that a former large employer in Loughborough had archive material destroyed or lost when the company was taken over by a larger corporation.

Although the material holds much interest for local enthusiasts, it is now extremely difficult to access the material, with some of it having been transferred to a closed corporate archive, some destroyed and some, allegedly, still in an old, forgotten office that is now owned by the larger corporation. What was once a complete and exhaustive archive that was actively used 
by local amateur historians has been lost for future generations due to the unwillingness of the larger corporation to manage it and provide access. It may be the case that these challenges are insurmountable due to the approach of the company. The project found that rather than considering contacting the regional repository records office, or even the local library, the archive was simply disposed of in various ways. This has led to much frustration in the town, where it is felt that part of their heritage has been lost through a careless approach to preservation of the corporate memory of the publisher. It led one interviewee to state that the large publishing company was not much liked in town because of this attitude.

These examples demonstrate that there is still a significant need to better promote the value of appropriate records and archive management for businesses so material is not lost. The findings from LoCHe underscore the discussion in the TNA strategy ${ }^{39}$ of the vulnerability of business archives. The Strategy identifies areas of risk, many of which are demonstrated here, including the rarity of professional teams to organise records and archives within businesses; the failure of business resulting in ad hoc rescues; the expansion of electronic records and the risk of loss of born-digital material; and the fact that mergers and acquisitions between companies leads to a loss of corporate archives. This research highlights that there is a risk for the business in not collecting and preserving its own material, as seen in the financial services company for example, but there may also be a risk in allowing community groups and individuals to perform this function instead. This allows stakeholders external to the business to have some control of the brand, but it is arguably better than having no stakeholder interest at all as the material will then almost certainly be lost and with it a source of brand identity and corporate memory. 


\section{Conclusions}

The picture of life in towns is in part bound up with its corporate heritage as companies can dominate the local economy and play huge roles in the lives of local families. There is a danger that this social heritage will be forgotten, certainly in Loughborough, as many companies do not always see the benefits of engaging with communities or the local authority archives. Material is therefore lost and this will only be increased with greater reliance on digital records as this is more difficult for communities themselves to collect and store successfully over time. For large companies this community will be much wider than SMEs, who have opportunities rooted in their local area, but this could be changing due to the opportunities form online and digital channels. However companies that could benefit from collecting archival material as shown in this study may be relatively uninformed about these opportunities and so currently have little interest. This seems especially the case for SMEs. Local authority archives are hard pressed to be able to support businesses however, but anniversary celebrations may be a trigger for attention to be paid to this within a company.

The situation examined in this paper is likely to be repeated in other towns, although further research to examine the patterns of engagement by business and communities and the risk of loss would be beneficial. Businesses that have an interest in their heritage need to engage 
with the community to drive collecting as use of the material brings benefits to all

stakeholders. It enables not only the business to benefit by engaging with the community, such as through open days or anniversary celebrations, but also the community benefits through accessing more business material for personal research, such as family history or writing books, by engaging with the local heritage and to enrich it through collecting material that is valued. Creativity in the community, better collections, community cohesion, better company reputation (and all the advantages this brings) and positive impacts on community engagement are all benefits that can be realized.

\footnotetext{
1 TNA, Corporate Memory, 2.

${ }^{2}$ Accessed 31.01.17 http://ec.europa.eu/growth/smes/business-friendly-environment/sme-definition_en

${ }^{3}$ Accessed 31.01.17

https://www.nomisweb.co.uk/reports/lmp/la/1946157142/report.aspx?pc=le11\%203tu\#tabrespop

${ }^{4}$ Accessed 06.05.17 http://www.leicestermercury.co.uk/charnwood-in-leicestershire-named-most-averageplace-in-england-and-wales/story-30056231-detail/story.html

${ }^{5}$ Accessed 06.05.17 http://www.charnwoodbusiness.com/pages/industrial_revolutions

${ }^{6}$ Accessed 06.05.17 http://web.ons.gov.uk/ons/data/dataset-finder//q/dcDetails/Economic/UKBAA03?p_auth=rIpE48yC\&p_p_lifecycle=1\&_FOFlow1_WAR_FOFlow1portlet_d ataset_navigation=datasetCollectionDetails

${ }^{7}$ TNA, National Strategy.

${ }^{8}$ Scottish Council on Archives, National Strategy.

9 TNA, National Strategy, 5.

${ }^{10}$ Ibid., 10.

${ }^{11}$ Cobbin et al., Accounting and Business Archives, 399.

${ }^{12}$ Accessed 31.01.17 http://www.archives.org.uk/about/sections-interest-groups/business-records-groupbrg.html

${ }^{13}$ Accessed 31.01.17 http://www.dpconline.org/handbook/introduction

${ }^{14}$ TNA, Corporate Memory, 20.

${ }^{15}$ Accessed 31.01.17 http://www.managingbusinessarchives.co.uk/getting_started/exploiting_the_archive/

${ }^{16}$ Deserno, International Business Archives, 216.

${ }^{17}$ Shepherd, Culture and evidence, 174.

${ }^{18}$ Megill, Corporate Memory, 14.

${ }^{19}$ TNA, National Strategy, 13.

${ }^{21}$ Accessed 31.01.17 http://www.fsb.org.uk/media-centre/small-business-statistics

${ }^{22}$ Gray, Developing the corporate memory, 14.

23 TNA, National Strategy, 10

${ }^{24}$ Gray, Developing the corporate memory, 36.

25 TNA Corporate Memory, 12.

${ }^{26}$ Ibid., 5.

${ }^{27}$ Flinn, Community Histories, 153.

${ }^{28}$ Ibid., 153.

${ }^{29}$ Ibid, 159.

${ }^{30}$ Barrett, Respect Which Fonds?, 77.

${ }^{31}$ Gilliland and McKemmish, Role of Participatory Archives, 2.

${ }^{32}$ Gilliland and Flinn, Community Archives, 2.

${ }^{33}$ Ibid., 9.

${ }^{34}$ Flinn, Community Histories, 166.

${ }^{35}$ Ibid., 19.
} 


\footnotetext{
${ }^{36}$ Gilliand and Flinn, Community Archives, 17.

${ }^{37}$ Accessed 06.05.17 http://www.nationalarchives.gov.uk/legal/copyright.htm

${ }^{38}$ Blue Ribbon Task Force, Sustainable Economics, 13.

39 TNA, National Strategy, 13.
}

\section{Bibliography}

Barrett, Creighton. “Respect Which Fonds? Personal Archies and Family Businesses in Nova Scotia.” Archivaria, 76 (2013): 75-92.

http://archivaria.ca/index.php/archivaria/article/view/13459

Blue Ribbon Task Force. "Sustainable Economics for a Digital Planet: Ensuring Long-Term Access to Digital Information”. 2010. http://brtf.sdsc.edu/biblio/BRTF_Final_Report.pdf

Cobbin, Phillip, Graeme Dean, Cameron Esslemont, Patrick Ferguson, Monica Keneley, Brad Potter and Brian West. "Enhancing the Accessibility of Accounting and Business Archives: The Role of Technology in Informing Research in Accounting and Business” ABACUS, 49, no.3 (2013): 396- 422. DOI: 10.1111/abac.12009.

Deserno, Ineke. "The value of international business archives: the importance of the archives of multinational companies in shaping cultural identity.” Archival Science, 9, no.3 (2009): 215-225. DOI 10.1007/s10502-009-9106-1.

Flinn, Andrew. “Community Histories, Community Archives: Some Opportunities and Challenges” Journal of the Society of Archivists, 28, no.2 (2007):151-176.

DOI:10.1080/00379810701611936.

Gilliland, Anne J. \& Flinn, Andrew. “Community Archives: what are we really talking about?” keynote paper presented at Nexus, Confluence, and Difference: Community 
Archives meets Community Informatics: Prato CIRN Conference, Prato Italy, October 28-30, 2013.

Gilliland, Anne J., \& McKemmish, Sue. “The role of participatory archives in furthering human rights, reconciliation and recovery.” Atlanti: Review for Modern Archival Theory and Practice, 24 (2014): 78-88. http://escholarship.org/uc/item/346521tf

Gray, Vic. “Developing the Corporate Memory: the potential of business archives.” Business Information Review 19, no.1 (2002): 32-37.

http://journals.sagepub.com/doi/abs/10.1177/0266382024238266

Megill, Kenneth A. Corporate Memory: Records and Information Management in the Knowledge Age. $2^{\text {nd }}$ ed. Munchen: KG Saur, 2005.

Shepherd, Elizabeth. "Culture and evidence: or what good are the archives? Archives and archivists in twentieth century England.” Archival Science, 9, no.3 (2009): 173-185. DOI 10.1007/s10502-009-9077-2.

The National Archives “Corporate Memory a guide to managing business archives.” The National Archives. 2009. http://www.nationalarchives.gov.uk/documents/information$\underline{\text { management/corporate-memory.pdf }}$

The National Archives “National Strategy for Business Archives (England and Wales).” The National Archives. 2009.

http://www.businessarchivescouncil.org.uk/materials/national_strategy_for_business_archive $\underline{\text { s.pdf }}$ 